Portland State University

PDXScholar

1973

\title{
A Survey for Leucocytozoon Simondi Mathis and Leger (1910) in Canada Geese of the Malheur Wildlife Refuge
}

John Val Snively

Portland State University

Follow this and additional works at: https://pdxscholar.library.pdx.edu/open_access_etds

Part of the Biology Commons

Let us know how access to this document benefits you.

Recommended Citation

Snively, John Val, "A Survey for Leucocytozoon Simondi Mathis and Leger (1910) in Canada Geese of the Malheur Wildlife Refuge" (1973). Dissertations and Theses. Paper 2140.

https://doi.org/10.15760/etd.2138

This Thesis is brought to you for free and open access. It has been accepted for inclusion in Dissertations and Theses by an authorized administrator of PDXScholar. Please contact us if we can make this document more accessible: pdxscholar@pdx.edu. 
AN ABSTRACT OF THE THESIS OF John Val Snively for the Master of Science in Biology presented May 3, 1973.

Title: A Survey for Leucocytozon simondi Mathis and Leger (1910) In Canada Geese of the Malheur Wildlife Refuge.

APPROVED BY MEMBERS OF THE THESIS COMMITTEE:
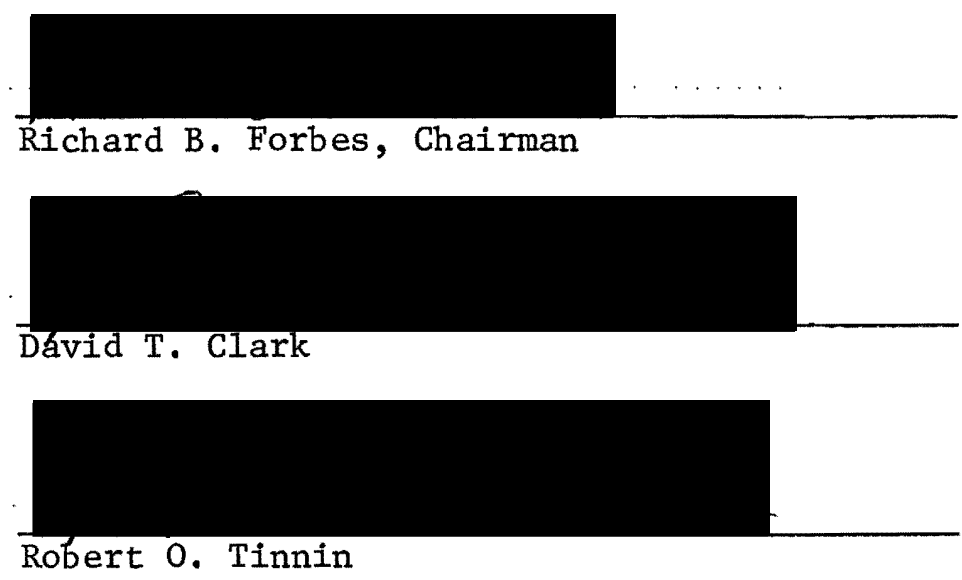

Blood smears of blood collected in 1971 and 1972 from 291 Canada geese at Malheur National Wildlife Refuge were examined to determine the incidence of the avian malarial parasite, Leucocytozoon simondi. No parasites were found. Absence of blood parasites suggests that birds using migration routes to the north and northeast of Malheur are free of the disease.

The Leucocytozoon infections known in California waterfow I may be attributable to sources within the flyway east or northeast of California, to infected birds crossing over from other flyways, or abnormal conditions in the molting grounds of sub-adult and non-nesting birds where major flyways converge in northcentral Canada. 
A SURVEY FOR LEUCOCYTOZOON SIMONDI MATHIS AND LEGER (1910)

IN CANADA GEESE OF THE MALHEUR WILDLIFE REFUGE

by

JOHN VAL SNIVELY

A thesis submitted in partial fullfillment of the requirements for the degree of

MASTER OF SCIENCE

in

BIOLOGY

Portland State University

1973 
TO THE OFFICE OF GRADUATE STUDIES:

The members of the Committee approve the thesis of John Val Snively presented May 3, 1973.

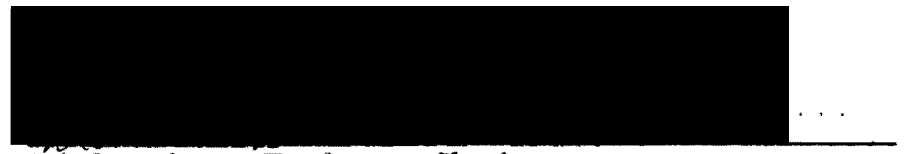

Richard B. Forbes, Chairman

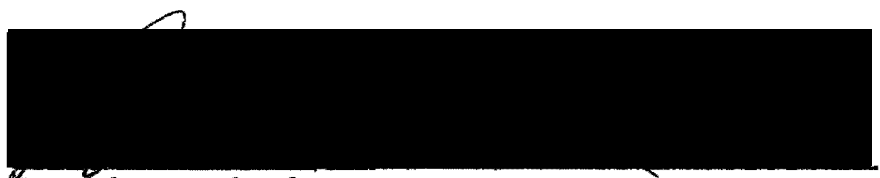

David T. Clark

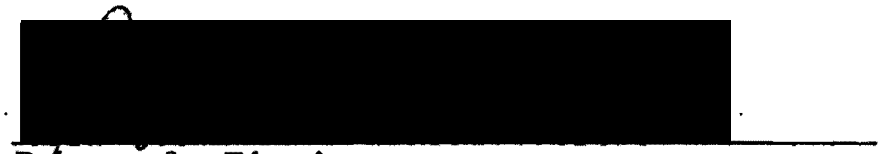

Robert 0. Tinnin

\section{APPROVED:}

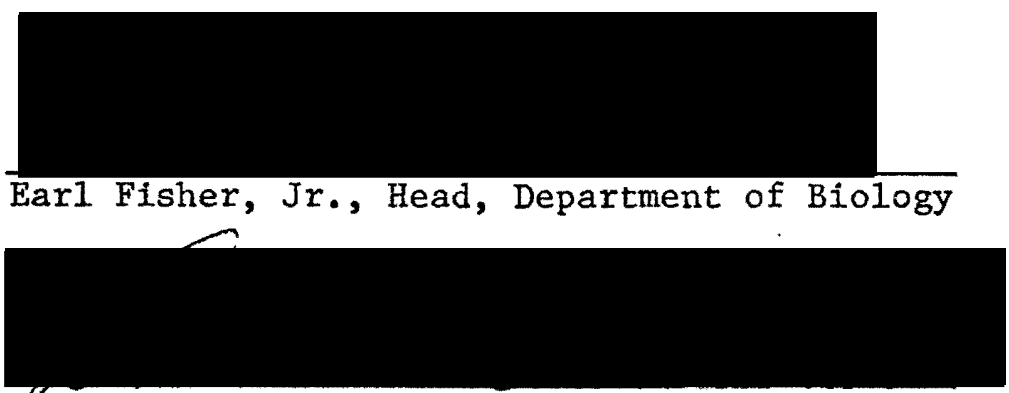

Bavid T. Clark, Dean of Graduate Studies 
TABLE OF CONTENTS

\section{PAGE}

ACKNOWLEDGEMENTS . . . . . . . . . . . . . . . .

LIST OF TABLES . . . . . . . . . . . . . . . . . . . iv

IIST OF FIGURES. . . . . . . . . . . . . . . v v

LITERATURE REVIEW. • . . . . . . . . . . . . . . 1

DESCRIPTION OF PROBLEM . . . . . . . . . . . . 5

MATERIALS AND METHODS. . . . . . . . . . . . 8

RESULTS AND DISCUSSION . . . . . . . . . . . . 10

CONCLUSIONS. . . . . . . . . . . . . . . 17

REFERENCES . . . . . . . . . . . . . . . . 18 
LIST OF TABLES

TABLE

PAGE

I Number of Canada Goose Leg Bands . . . . .

II Age Distribution of Sampled Canada Geese . . 
LIST OF FIGURES

1. General migration routes of geese banded at the Malheur National Wildlife Refuge . . . . . 


\section{ACKNOWLEDGEMENTS}

The author expresses his most sincere thanks to Dr. David T. Clark for his guidance and assistance; to Drs. Richard B. Forbes and Robert 0. Tinnin for their constructive criticisms of this manuscript.

Special gratitude is extended to Mr. Joe Mazzoni, Refuge Manager, and Mr. Eldon L. McLaury, Wildlife Biologist, Malheur National Wildlife Refuge, for their assistance in obtaining blood samples and migration data for this study.

Appreciation is given to Mr. John Chattin, Flyway Director, Bureau of Sports Fisheries and Wildlife for providing data on Canada goose migrations. 


\section{LITERATURE REVIEW}

Leucocytozoon simondi Mathis and Leger (1910) is a parasitic protozoon causing a malaria-like disease in ducks and geese. Numerous authors (e.g., Fallis, Davis, and Vickers, 1951; Chernin, 1952; Kocan, 1968) have implicated Leucocytozoon simondi as a major pathogen of North American waterfow1. The parasite was first described from the Oriental teal (Querquedula crecca) and has since been found in approximately 26 species of ducks and geese. Early workers described several species of Leucocytozoon from various hosts. Current workers, in response to a review by Herman (1938), recognize only Leucocytozoon simondi Mathis and Leger (1910) as common to members of the avian family Anatidae.

Leucocytozoon in ducks and geese frequently causes high rates of morbidity and mortality in northern Michigan and Ontario, Canada. 0'Roke (1934) reported that in commercially raised ducks in northern Michigan, mortality rates frequently reached $100 \%$. Young geese of the Seney Wildlife Refuge in Michigan have exhibited mortality rates of $80 \%$ from Leucocytozoon in some years (Herman, 1968).

The parasite is transmitted from one definitive host to the next by certain species of blackflies of the family Simuliidae. While not all species of blackflies are natural vectors, numerous species of the Simuliidae have been implicated as probable vectors (0'Roke, 1934; Fallis, Anderson, and Bennett, 1956; and Tarshis and Herman, 1965). Suitable species of blackflies become infective vectors by ingesting gametocytes present in the peripheral blood of an infected avian host. 
Exflagellation of the microgametocyte occurs within several minutes after ingestion. Fallis, Davis, and Vickers (1951) found zygotes were common in the stomachs of blackflies two hours after ingestion and subsequent oocysts were present in the stomach 40-48 hours after blackflies fed on infected birds. Immature oocysts penetrate the stomach wall, mature, and divide into sporozoites which migrate to the salivary glands of the blackflies. Fallis, Davis, and Vickers (1951) showed that sporozoites capable of infecting an avian host were present in the salivary glands of the blackfly, Simulium.rugglesii, three to four days after becoming infected and that blackflies were capable of transmitting L. Simondi for up to 18 days after ingesting the gametocytes.

General features of the parasite-host interaction within the avian host have been described by numerous workers (e.g., Chernin, 1952; Cowan, 1955; Kocan and Clark, 1966; Desser, 1967; and Kocan, 1968). Hepatic schizonts are found in the liver on the fourth day of infection (Desser, 1967). Merozoites produced by hepatic schizonts give rise to second generation hepatic schizonts, round gametocytes, and megaloschizonts which are found in other organs and produce elongate gametocytes. Both forms of gametocyte, round and elongate, are found in the peripheral blood of the avian host and may continue the life cycle by infecting feeding blackflies. Desser (1967) has shown that schizogamy can be completed and both forms of gametocytes are found in the avian blood within eleven days from infection.

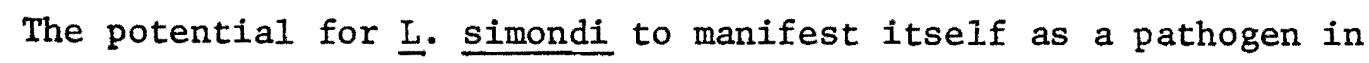
a specific geographic area is related to important aspects of its epidemiology. $0^{\prime}$ Roke (1934) outlined the general pattern of the life 
cycle and provided a basic understanding of the relationships between the parasite, the vector, and the host bird. He noted the following: (1) host birds surviving the initial infection exhibit lower levels of parasitemia seasonally until it becomes exceedingly difficult to detect, though present, during the winter months; (2) adult biackflies do not overwinter; (3) the parasite reappears (spring relapse) in abundance the following spring in the peripheral blood of the bird; (4) the spring relapse coincides with the emergence of new blackfly populations. From these and other observations, O'Roke concluded that the bird is the host in which the parasite (in low numbers) survives from one season to the next and the relapse (associated with high parasite density in the peripheral blood of the host) provides a reservoir of parasites which can infect the new generation of simulid vectors.

Winter months separate the period of primary parasitemia from that of relapse. Supporting 0'Roke's conclusions, Chernin (1952) found that there was no month when gametocytes, though in very low numbers, could not be found in the circulating blood. Immature gametocytes represented $20 \%$ of the total parasite count indicating that some asexual reproduction may occur throughout the winter. Thus, infected birds carry a very low grade of chronic infection until they effect self-cure or relapse occurs. Chernin (1952) has demonstrated that the relapse phenomenon may be related to physiological changes associated with the onset of reproductive activity.

In summary, the transmission of $\underline{L}$. simondi from one generation of birds to the next requires close timing of several critical events. The relapse of adult birds provides sufficient gametocyte numbers in 
the circulating blood to infect feeding blackflies while at their greatest seasonal population level, thus providing a maximum number of infected blackflies. These events coincide chronologically with the hatching of uninfected and highly susceptible ducks and geese on which the flies feed and transmit the disease to new avian hosts. 


\section{DESCRIPTION OF PROBLEM}

The purpose of this investigation was to obtain data on the presence or absence of $\underline{\mathrm{L}}$. simondi in Canada geese; Branta canadensis, in southeastern Oregon as an indicator of the parasite's source of infection In the Pacific flyway. There have been relatively few surveys for Leucocytozoon in the flyway. Wood and Herman (1943) and Clark and Swinehart (1966) have reported Leucocytozoon spp. from 32 species of birds other than the Anatidae from southwestern California. Clark, Lee, and Lieb (1968) added another six species of hosts from the central Washington region. More importantly, Wood and Herman's survey in California found $21 \%$ of 67 ducks and geese infected with $\underline{L}$. simondi. A later paper by Herman (1951) reported only $2 \%$ of southwestern California ducks and geese positive for $\underline{L}$. simondi. Neither the localities nor the time of year of collection was recorded for either of the California surveys. The occurrence of $\underline{L}$. simondi in California is significant because it is one of the major wintering areas for waterfow 1 of the Pacific flyway (Table I).

A complete list of species of Oregon blackflies and their distribution is not yet available. A preliminary survey by Smith (1963) lists at least 12 species native to Oregon. Of those listed as occurring in Oregon, Simulium venustum Say has long been considered a possible vector for I. Simondi. Fallis, Davis, and Vickers (1951) found s. venustum to harbor $L$. simondi to the infective stage; however, the effectiveness of $\underline{S}$. venustum as a natural vector remains in question even though the species is known to feed on waterfowl. Other species of Simuliidae which have not been reported in Oregon have been shown positively by Fallis and Bennett (1966) to be vectors of $\underline{L}$. simondi. 
TABLE I

NUMBER OF CANADA GOOSE LEG BANDS RETURNED EXPRESSED

AS A PERCENTAGE OF THE TOTAL

NUMBER OF BANDS ATTACHEDI

\begin{tabular}{|c|c|c|c|}
\hline AREA OF BANDING & $\begin{array}{l}\text { BANDS RETURNED }{ }^{2} \\
\text { LOCALLY } \\
\end{array}$ & $\begin{array}{l}\text { BANDS } \\
\text { FROM } \\
\end{array}$ & $\begin{array}{l}\text { TURNED } \\
\text { I FORNIA }\end{array}$ \\
\hline Southcentral Saskatchewan & 28.8 & 2.6 & $(3.6)^{3}$ \\
\hline Southcentral Alberta & 39.7 & 13.4 & $(22.2)$ \\
\hline Northwest Montana & 74.6 & 0.5 & $(2.0)$ \\
\hline Northcentral Montana & 32.0 & 8.5 & $(12.4)$ \\
\hline Eastcentral Idaho & 50.0 & 9.7 & $(19.0)$ \\
\hline Westcentral Idaho & 88.8 & 1.5 & $(12: 8)$ \\
\hline Northwest Wyoming & 53.4 & 8.7 & $(18.8)$ \\
\hline Northwest Utah & 51.8 & 14.7 & $(30.5)$ \\
\hline Northeast Wyoming & 20.3 & 16.5 & $(20.6)$ \\
\hline
\end{tabular}

1. Information sunmarized in 1969 by John Chattin, Pacific Flyway Director, Bureau of Sport Fisheries and Wildlife, Portland, Oregon.

2. Birds killed, prior to migration, near site of banding.

3. Figure in parenthesis is number of bands returned expressed as a percentage of the number of banded birds migrating from the banding site.

Note: Although banding returns are supplied, in large part, by hunting activity in the fall and many of the birds are killed in route to the wintering area, banding data do provide some indication of the importance of central California as a wintering area for waterfowl. The relatively high incidence of locally recorded birds probably represent juvenile birds killed by hunting and reflect a correspondingly low incidence of birds reaching central and south California. 
The presence of $\underline{I}$. simondi in the wintering grounds of western waterfow1 suggests that some of the nesting areas to the north and northeast of California are enzootic for the disease. If Leucocytozoon is not found to be transmitted in the nesting areas, infected birds in California reported by Wood and Herman (1943) may represent crossover of migrating geese from other fiyways. Too few surveys of blood parasites have been made in the Pacific flyway to resolve this question. North American waterfowl are an important economic and esthetic resource. Continued hunting pressure and loss of nesting habitat have served to reduce some species' populations to dangerously low levels. The added burden of a pathogen is therefore a major concern to those in charge of wildlife management. 
In cooperation with the Fish and Wildlife Service, blood samples of Canada geese were taken on two separate occasions at the Malheur Wildlife Refuge, Harney County, Oregon. Geese are banded annually on the Malheur Refuge in conjunction with a continental goose management program by the United States Fish and Wildlife Service. The site of the goose "roundup" was Knox Pond located at W. M., Sec 17, R31S, R32.5E.

On June 23, 1971 and June 22, 1972, geese were driven into a wire enclosure where they were held for orderly processing. They were removed from the enclosure one at a time, and personnel of the Malheur Wildlife Refuge determined sex, age, and applied leg bands.

Blood samples were collected from 215 of 376 Canada Geese during the 1971 survey. The following year, 1972, 76 blood samples were taken from a total of 94 geese captured. Blood smears were made by clipping a toe or by needle puncture of the tarsal vein located on the medial aspect of the tarsometatarsal region of the leg.

The technique described by Bennett (1962) for improved diagnosis of haemosporidia infections was used for 21 samples of the 1972 survey. For this procedure, blood is drawn into heparinized hematocrit capillary tubes and sealed with a plug of plasticine. The tubes are centrifuged for ten minutes at 15,000 rpm, separating the red and white blood cells. The hematocrit tubes are broken where the packed cells and plasma interface. Smears were made of the white blood cells which layer on the red blood cells and stained.

A11 blood smears and smears of white blood cells from hemacrit tubes were made on standard pre-cleaned $2.5 \times 7.5 \mathrm{~cm}$ glass slides on 
which the bird's band number had been etched to facilitate age and sex correlations if $\underline{L}$. simondi was found.

Al1 smears were stained with Wright's stain using $0.1 \mathrm{~g}$ of Wright's stain powder (Matheson Co., Inc.) to $60 \mathrm{ml}$ of absolute methyl alcohol. The buffer ( $\mathrm{pH}$ 6.4) for dilution of Wright's stain consisted of $6.63 \mathrm{~g}$ of potassium phosphate $\left(\mathrm{KH}_{2} \mathrm{PO}_{4}\right), 2.5 \mathrm{~g}$ of anhydrous sodium phosphate $\left(\mathrm{NaHPO}_{4}\right)$ and enough distilled water to make one liter of solution. The slides were covered with stain for three minutes and then flooded with an equal amount of buffer. After an additional 3.5 minutes, the stain and buffer were removed with tap water and the slide allowed to air dry.

Each slide was examined for 20 minutes: ten minutes at $100 \mathrm{X}$ and ten minutes at 430X. Further, all slides from birds three years or older were reexamined an additional ten minutes at $160 \mathrm{X}$. 


\section{RESULTS AND DISCUSSION}

The results of this survey show that Leucocytozoon did not occur In 291 Canada geese (Branta canadensis) captured at the Malheur Wildlife Refuge in June of 1971 and 1972. Included in the sample of geese were nesting adults and newly hatched goslings. No juvenile birds were captured. Summary data are presented in Table II.

Since adult birds were negative for the pathogen, it would seem likely that the routes of subadult and non-nesting adult birds en route to and including the molting areas are also free of Leucocytozoon infections. These areas have not been surveyed for Leucocytozoon simondi. Data obtained from 354 Canada goose band returns indicate that subadult geese and unsuccessful nesting birds move north through the Malheur Valley in the spring and migrate to molting areas to complete their postnuptual molt (letter dated 6 February 1973 from Joe Mazzoni, Refuge Manager and Eldon McLaury, Wildlife Biologist, Malheur Wildlife Refuge, Oregon). While a few of the Malheur birds molt in subsequent years at Cow Lakes in southeastern Oregon, evidence from band returns indicate that many Malheur geese molt in northern Alberta or Saskatchewan or, more likely, the Northwest Territories, Canada. The exact molting site is unknown.

Birds returning from the molting area seem to follow two routes (Figure 1). There is a divergence of routes in the area of southeastern British Columbia, Canada, or southcentral Alberta, Canada, and northern Montana, Idaho, and Washington. Part of the flock follows the Columbia River drainage southward and then across eastcentral Oregon back to Malheur before moving into California for the winter. The other portion 
TABLE II

AGE DISTRIBUTION OF SAMPLED

CANADA GEESE

1971

1972

AGE GROUP

\# Birds $\quad$ Infected

\# Birds \%Infected

Adult males

18

0

6

0

Adult females

15

0

6

0

1 year old males

0

0

0

0

1 year old females 0

0

0

0

Immature males

88

0

19

0

Imnature females

75

0

38

0

Unknown

$\frac{19}{215}$

$\frac{0}{0}$

$\frac{7}{76}$

0

Tota1

76

0 


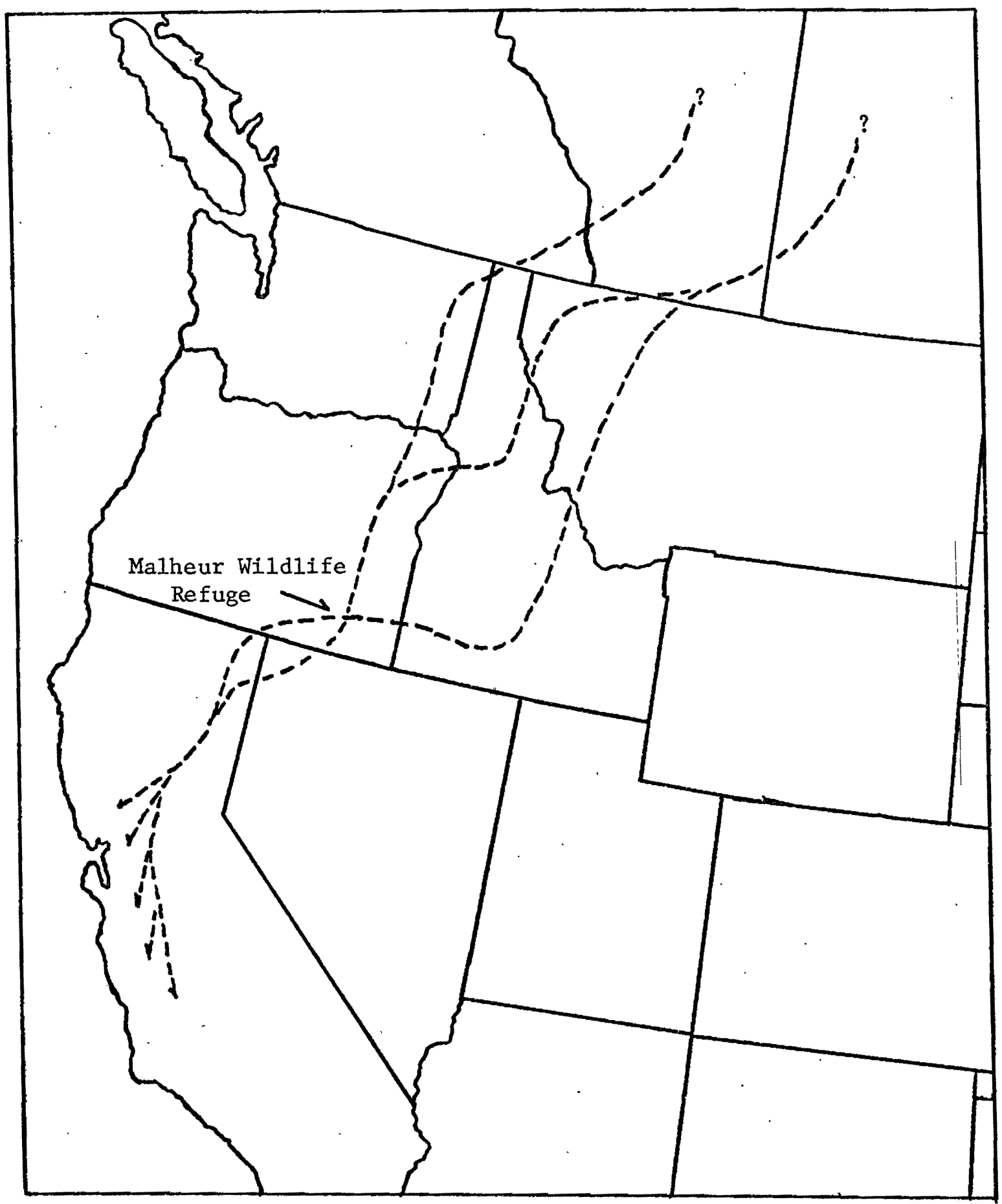

Figure 1. General migration routes of geese banded at the Malheur National Wildlife Refuge. Second year birds and nonnesting adults fly north to molt during the summer. In the fall migration, the geese pass through the Malheur Valley and then into central California. 
passes south through westcentral Montana to the Flathead Lake region and then down the Salmon River drainage while some may move through central Montana and south to the vicinity of American Falls, Idaho; then to the Lake Lowe11-Snake River area and then westward back to Malheur (letter dated 6 February 1973, Mazzoni and Mclaury).

Since the subadult birds move through these areas during the blackfly season and do not become infected, there is good reason to believe that the areas along the migration routes are not presently conducive to infection of waterfowl by $\underline{L}$. simondi.

Very little is known regarding the molting localities of Pacific flyway geese. Sterling and Dzubin (1967) have provided evidence that the Beverely-Aberdeen Lakes, Northwest Territories, Canada, is one of the most important molting grounds for geese of the Mississippi flyway. Molting geese banded on the Beverely-Aberdeen Lakes molting ground, however, are recovered throughout the Central and Pacific flyway. Sterling and Dzubin, (1967) and Kuyt (1966) banded molting geese at lookout point on the Middle Thelon River and found a large portion of the birds were recovered in the Central flyway. This site is located 75 miles from the Beverely-Aberdeen Lakes area. Sterling and Dzubin (1967) recorded $47 \%$ of molting geese banded at Lookout point were recovered in the Pacific flyway with birds recovered in Oregon, Washington and California. The Thelon-Back Rivers drainage system has not been shown to be a major molting area for the smaller subspecies of Branta canadensis, but within a radius of 40 miles, the area seems to be a focal point for molting of the larger subspecies of $\underline{B}$. canadensis from the Pacific, Central, and Mississippi flyways. Presumably, then, 
geese infected with $\underline{\underline{L}}$ simondi from the Mississippi flyway are molting with or adjacent to subadult geese of the Pacific flyway. This would seem to be an area of prime concern because of the potential for spread of infection through the major continental migration routes. No one, as of yet, has investigated the epidemiology of $\underline{L}$. simondi in the Thelon-Back drainage system.

Sterling and Dzubin (1967) were impressed with the distinct segregation of migrating groups during the molting season. Geese maintained their flock integrity even when forced together for banding purposes. Such a mechanism of group separation may serve to prevent the spread of disease between neighboring molting birds.

It is interesting to note that although the Thelon-Back Rivers drainage system is recognized as an ancestral molting ground, records indicate the area was scarecely used by geese from the turn of the century to the mid 1950's (Sterling and Dzubin, 1967). It is during this period of disrupted migration behavior that Wood and Herman (1943) reported a high incidence of $\underline{L}$. simondi in wintering waterfowl from California. This correlation suggests that another study of California is in order to see if Leucocytozoon infections in the Pacific flyway are related to a disruption in behavior, for whatever causes, in the molting areas. If $\underline{L}$. simondi is presently absent, during a period of normal molting activity, there might be sufficient cause to impose limitations of human activity on molting grounds throughout the molt season.

If suitable blackfly vectors are present in the Thelon-Back Rivers system, one might expect Leucocytozoon infections to be present only 
sporadically in the Pacific flyway as a result of some groups of migrating birds molting in close proximity to infected birds from other flyways. Related to this, Sterling and Dzubin (1967) reported that harassment of molting geese caused the birds to desert their traditional molting area for the following years. Increased oil exploration, mining, canoeing and other recreational activities in the area may serve to disrupt ancestral molting areas to the enhancement of the transmission of $\mathrm{L}$. simondi among geese in that area.

Although Malheur geese are not known to molt in the Thelon-Back drainage, band returns indicate they are coming from that general area. More extensive ground and aerial surveys are needed in waterfow 1 molting grounds to delineate the specific molting areas of specific breeding populations. Only then can we assess the potential for interflyway transmission of $\underline{\text { L. }}$ simondi.

So long as subadult and non-nesting birds do not become infected en route to and in molting areas there is little chance of the introduction of $\underline{L}$. Simondi to Malheur geese since a reservoir of parasites cannot materialize without infected birds.

Currently, there is insufficient information regarding Oregon blackfly species and their distributions. A better understanding of vector distribution is required before a credible assessment of the potential transmission of $\underline{L}$. simondi can be made for nesting areas in the state.

The source of infection in California waterfowl is still unknown. Since the Malheur birds are free of Leucocyctozoon it is unlikely that the infected birds from California used the same migratory routes as 
do southeastern Oregon birds. If they do use the same routes, vector species are probably absent along the migration routes during the migration. It is also unlikely that they all represented birds which crossed over from other flyways since an infection incidence of $21 \%$ is very high for flyway crossovers. Banding in northeast Wyoming (Central flyway) yielded $16.5 \%$ recovery in California but this would require nearly $100 \%$ infection of Leucocytozoon in that area to account for the high incidence in California birds. With information now avallable, a possible explanation for the occurrence of $\underline{L}$. simondi Infections in California waterfowl is that the infections originate from a more easterly locality from within the flyway; or perhaps they result from aberrant conditions which may occur in the molting area of subadult birds. .

These speculations suggest a need for additional study of blackflyLeucocytozoon epizooitology as they relate to waterfowl in the Pacific flyway.

The incidence of Leucocytozoon in duck populations at the Malheur Wildlife Refuge is not known; however, it has been reported by Wood and Herman (1943) that the parasite does occur in ducks of the Pacific flyway. Should it be found that Leucocytozoon occurs in ducks hatched at Malheur but not in geese, there would be evidence indicating, that the species of Leucocytozoon in geese is different from that of ducks. 


\section{CONCLUSIONS}

Blood smears of blood collected in 1971 and 1972 from 291 Canada geese at Malheur National Wildlife Refuge were examined to determine the incidence of the avian malarial parasite; Leucocytozion simondi. No parasites were found. Absence of blood parasites suggest that birds using migration routes to the north and northeast of Malheur are free of the disease.

The Leucocytozoon infections known in California waterfowl may be attributable to sources within the flyway east or northeast of California, to infected birds crossing over from other flyways, or abnormal conditions in the molting grounds of sub-adult and non-nesting birds where major flyways converge in northcentral Canada. 
Bennett; G. F. 1962. The hematocrit centrifuge for the laboratory diagnosis of hematozoa. 'Can. I. Zool. 40:124-125.

Chernin, E. 1952. The relapse phenomenon in the Leucocytozoon simondi infection in the domestic duck. 'Am: J. Hyg. 56:101-118.

Clark, G. W., and B. Swinehart. 1966. Blood protozoa of passerine birds of the Sacramento (California) region. 'Bull. Wild1. Dis. Assoc. 2:53-54.

M. A. Lee, and D. E. Lieb. 1968. Avian hematozoa of central Washington. Bull: Wildl. Dis. Assoc. 4:15.

Cowan, A. B. 1955. The development of megaloschizonts of Leucocytozoon simondi, Mathis and Leger. J. Parasitol. 2:158-167.

Desser, S. S. 1967. Schizogony and gametogany of Leucocytozoon simondi and associated reactions in avian host. J. Protozool. 14:244-254.

Fallis, A. M., R. C. Anderson, and G. F. Bennett. 1956. Further observations on the transmission and development of Leucocytozoon simondi. Can I. Zool. 34:389-404.

, and G. F. Bennett. 1966. On the epizooitology of infections caused by Leucocytozoon simondi in Algonquin Park, Canada. Can. J. Zoo1. 44:101-111.

, and D. M. Davis, and M. A. Vickers. 1951. Life history of Leucocytozoon simondi Mathis and Leger in natural and experimential infections and blood changes produced by the avian host. Can. J. Zool. $29: 305-328$.

Herman, C. M. 1938. Leucocytozoon anatis Wickare, a synonym for $\underline{L}$. simondi Mathis and Leger. J. Parasitol. 24:472-473.

- 1951. Blood parasites from California ducks and geese. J. Parasito1. 37:280-282.

- 1968. Blood parasites of North American waterfow1. pp. 348359. In J. B. Trefethen (ed.). Trans. Thirty-third N. Am. Nat. Resour. Conf. Wildlife Management Institute. Wire Building, Washington, D. C.

.Kocan, R. M. 1968. Anemia and mechanism of erythrocyte destruction in ducks with acute Leucocytozoon infections. J. Protozool. $15: 455-562$.

and D. T. Clark. 1966. Anemia in ducks infected with Leucocytozoon simondi. J. Protozool. 13:465-468. 
Kuyt, E. 1966. Further observations on large Canada geese molting on the Thelon River, Northwest Territories. Canad. Field Nat. $80: 63-69$.

O'Roke, E. C. 1934. A malaria-like disease of ducks caused by Leucocytozoon anatis Wickare. Univ. Mich. Sch. of Forestry and Conservation. Bull. No. 4. 44pp.

Smith, D. R. 1963. Blackflies of Oregon (Diptera: Simuliidae). 6161 U. S. A. R. Research and Development Unit. MED 394. Oregon State University. Corvallis, Oregon.

Sterling, R., and A. Dzubin. 1967. Canada goose molt migrations to the Northwest Territories. pp. 355-373. In J. B. Trefethen (ed.). Trans. Thirty-Second N. Am. Nat. Resour. Conf. Wildlife Management Institute. Wire Building, Washington, D. C.

Tarshis, I. B., and C. M. Herman. 1965. Is Cnephia invenusta (Walker) a possible important vector of Leucocytozoon in Canada geese? Bu11. Wild1. Dis. Assoc. 1:10-11.

Wood, S. F., and C. M. Herman. 1943. The occurrence of blood parasites in birds from southwestern United States. J. Parasitol. 29:187-197. 